\title{
THE PRESENT VALUE OF COMPARATIVE JURISPRUDENCE
}

\author{
C. E. A. BEDWELL \\ Keeper of the Middle Temple Library, London
}

Throughout the proceedings of the Peace Conference the delegates of the British Empire stood on more than one occasion as conciliators of different views held by representatives of the United States, France and Italy. Similarly it may be that the legal system of the British Empire has a corresponding function to fulfill in bringing about a rapprochement between the legal systems of the United States and European countries. The affinity between the English-speaking peoples based upon the strong attachment to the English common law and its great traditions is so strongly embedded in the life of the nations that its permanency seems to be secure. But the development of international relations may naturally arouse a desire among the jurists as well as other citizens of the continental countries for closer union with English lawyers. ' It is meet and right that this desire should receive cordial reciprocity. Professor Lambert of the University of Lyons has given expression to it in a monograph on the teaching of comparative law to which he gives the sub-title: "sa co-operation au rapprochement en la jurisprudence française et la jurisprudence anglo-americaine." The learned professor fully appreciates the binding force of the English common law but at the same time he directs attention to its French foundations. When the parting of the ways between the French and English systems took place at the end of the thirteenth century it was as Pollock and Maitland observed:

"Not about what may seem the weightier matters of jurisprudence do these sisters quarrel, but about 'mere matters of procedure,' as some would call them."1

There remains, therefore, an affinity between the systems of French and English law. Whatever may be the practical value in the present day of the historic connection, there are certainly opportunities for closer co-operation between lawyers on both sides of the Channel as there are on both sides of the Atlantic. Professor Lambert is concerned with the subject more particularly from the point of view of a professor in one of the great French Universities. He desires to see the University Library equipped with the statutes and reports of the United Kingdom and United States so that students of the university may have some opportunity to broaden their knowledge. Professor

\footnotetext{
${ }^{2} 2$ Pollock and Maitland, History of English Law (2d ed. 1899) 673.
} 
Lévy-Uhlmann of Liège University in an admirably informed paper ${ }^{2}$ read before the French Society. of Comparative Legislation has put the matter in a more practical form and appealed to the English Society to provide the material, especially by means of a bibliography of English law, so that the student in France or other countries may be assisted to study either the main principles or the special branches of English law. With this plea from the point of view of the French University Professor may be associated the admirable paper read by Professor Cammeo of Bologna University upon the nomination of the Italian government before the American Bar Association. ${ }^{3}$ At that time the war was taking the most prominent place in the minds of all men, but the prescience shown in the selection of the subject, having regard to the problems which would arise "from the settlement that the nations will require when the battle is over" is now apparent. One of the first practical results of the Peace Conference was the establishment of a permanent organization for the internal regulation of labor conditions. - The preamble to the convention gave some ideas of the wide range of subjects which will come' within its purview. They include:

The regulation of the hours of work, including the establishment of a maximum working day and week, the regulation of labour supply, the prevention of unemployment, the provision of an adequate living wage, the protection of the worker against sickness, disease and injury arising out of his employment, the protection of children, young persons, and women, provision for old age and injury, protection of the interests of the workers when employed in countries other than their own, the recognition of the principle of the freedom of association and organization, of technical and vocational education, and other measures.

Thus the laws of all the signatory countries bearing upon the relations of employers and employed will come under review, and it is proposed to publish in English and French a periodical in which all problems relating to the international character of industry and employment will be discussed. ${ }^{4}$ The need for a more comprehensive publication is obvious, since even to the best informed mind a collection of documents cannot take the place of a reasoned consideration of a subject. The monthly review of the Bureau of Labor Statistics of the United States Department of Labor is the kind of publication for which the international organization should make itself responsible, and Washington as its first place of meeting was the obvious

${ }^{2}$ Bulletin Mensuel de la Société de Legislation Comparée, Nos. I, 2, 3 (Igrg) 64.

${ }^{3} 43$ Reports of American Bar Association (I9I8) 303.

- Presumably this publication will take the place of the Bulletin of the International Labor Office formerly published in Switzerland and now issued from Paris which contains only the texts of laws and a bibliography of the literature on the subject. 
choice. But in order that its influence and the work of the international body as a whole may be effective it will be necessary for each signatory to have a corresponding body and organ for the enlightenment of public opinion upon the great problems of labor not only of its own country but of others which are allied with it. The workingmen and employers of Great Britain in making changes will need to appreciate the effect if they desire them to be adopted readily in Japan or Italy. There will be' a special presentation of the problems considered by the international body to be submitted to each country in accordance with its own particular needs. Unity of action based upon common guiding principles will not necessarily involve a stereotyped uniformity of legislative enactment for all parties to the international convention, so that the divergencies of each will be of interest to the others.

Although labor problems will be among the most important matters upon which the permanent Secretariat will require information, there will be a number of others. ${ }^{5} \mathrm{Mr}$. Reinsch in his admirable treatise upon Public International Unions ${ }^{6}$ has set forth details-of the various bureaux which had been formed for dealing with matters of communication, economic interests, sanitation and prison reform, police powers and scientific purposes. He writes:

"The bureau is the connecting link between the various national administrations. It furnishes them information about the interests of the particular union, acts as intermediary between the governments, and carries out the specific administrative duties assigned to it in the règlement."

The bureau not only collects but also disseminates information. It is reasonable to anticipate a development of its activities under the new régime. Transport is one of the most important matters to. receive international attention. Already an international aircraft convention has been one of the first subjects upon which general agreement was necessary before development in each country could make progress. Similarly further advance may be expected in the efforts already made to unify maritime law and the law relating to transport by land: The duties of a common carrier have already been defined so as to exclude national differences of interpretation and can be enforced in points that concern the acceptance, care, and delivery of merchandise. An allied subject which will come within the purview of

\footnotetext{
${ }^{5}$ See the provisions of Article 24 of the League of Nations Covenant quoted in (I9I9) 29 YALE Law Journal, 209, note.

${ }^{B}$ Reinsch, Public International Unions, their Work and Organization. (2d ed. I9I6).

${ }^{7}$ Reinsch, op. cit., I55.
} 
the International Transit Commission is the law regulating transport by river.

While, however, Professor Cammeo recognized that the constitution of the League of Nations would lead to a more general movement for the unification of law he considered that it must not go further than is required for the purpose of securing unity among the nations upon essential points. He said:

"I take it for granted that those branches of the law which are strictly connected with, and dependent upon, the main features of each nation that go to the root of its more peculiar ethnical, historical, political, economic tendencies, will remain outside the scope of unification. So it will be for constitutional law, for the law of domestic relations, for that of tenure of land, and of inheritance; for criminal law and for procedure, civil and criminal. The work of unification, I believe, will be confined to the law of ownership of moveable things, to the law of contract and torts, to commercial and maritime law, and to some points of that bratich of public law, which on the European continent is called administrative law. To sum up, I deem that unification should reach every field of law directly or indirectly connected with international trade. A world-wide trade will require world-wide legislation."'s

Though direct efforts to secure greater uniformity of legislation may be limited within the sphere suggested by Professor Cammeo there is no necessity for the student of comparative legislation to impose any such restraint upon himself. Comparative legislation, forbidding though its name is to the ordinary man, is commending itself to his approval by the extent to which it is assisting him to deal with the ordinary practical affairs of everyday life. In such matters as infant welfare legislation, which closely affects family life, the experience of one country is of considerable importance to the advocates of reform in other countries. The law of domestic relations to which Professor Cammeo especially alludes happens to provide an example of the way in which the continental system of law supplies a suggestion to fill a serious gap in the Anglo-American system of law.

The care of the children of the men who gave their lives in the military service of their country is one of the first duties of the State at the present time. The English law only regards the father's death in the same way as the popular phraseology, which describes it as the "loss of the breadwinner." It takes little or no interest in the orphans unless they are possessors of property, though the old custom of the City of London by which all orphans of freemen became wards of the Orphans Court of the Corporation serves to show that one important body recognized its weakness and made provision at least for their training in a trade as well as for the custody of their goods. ${ }^{9}$ The

\footnotetext{
${ }^{5} 43$ Reports of American Bar Association (I9I8) 303, 306.
}

- Bohun, Privilegia Londini (3d ed. I723) 3т3-36. 
operation of the court, though still authorized by law, has fallen into desuetude. ${ }^{10}$ The French and Italian systems of law, on the other hand, being based upon the old Roman law, recognize that by the father's death the family is deprived of the patria potestas. In order to provide, so far as possible, for this loss there was developed in the course of centuries the family council, ${ }^{11}$ whose constitution and authority were embodied in the French Civil Code and thence have been adopted with almost identical features in nearly all the continental systems of Europe. The desire to continue the same home for the children and to avoid the loosening of family ties, is also a characteristic of the provisions of the continental codes of law relating to guardianship. In order to appreciate more fully the position of the family council in the foreign systems of law it may be well to state its constitution. The family council ${ }^{12}$ consists, with the justice of the peace, of six relatives, half paternal and half maternal, residing in the parish, or within twelve miles from the domicile of the minor, and when there is not a sufficient number of relations, the justice of the peace then appoints persons who had been intimate with the father or mother of the child. ${ }^{23}$ According to the rule of the old Roman law, women, with the exception of the mother and grandmother, were excluded from the family council, but during the recent war this disability was removed in France. ${ }^{14}$ Similarly it might be shown that in other subjects excepted by Professor Cammeo as being outside the work of unification there is much to be gained by a close study and adoption of laws of other countries. The Torrens system of land registration, for example, has been found to be applicable with modifications to such varying conditions as exist in the Philippine Islands, Egypt, India, and the Australian States. ${ }^{15}$ Other examples might be given from his list of accepted subjects but there is no need to labor the point since it should be clear that nations like individuals can gain by the right use of the knowledge and experience of others.

The British Empire provides a peculiarly favorable sphere for the operations of the legislatures in the direction of uniformity. Under

${ }^{10}$ Eversley, Domestic Relations (3d ed. I906) 6 I5.

"Larousse, Grand Dictionnaire Universel, tit. Conseil de famille; Dalloz, Jurisprudence generale (I897) tit. Minorité; Maleville, Analyse raisontnée de la discussion du Code Civil, no. I, tit. ii.

${ }^{12}$ Aird, Civil Laws of France, 53.

${ }^{13}$ French Civil Code, Art. 409. 'The provisions that non-relations may be members of the family council exists also, for example, in Quebec, Spain, and St. Lucia. See Burge, Commentaries on Colonial and Foreign Laws (Ig07) 50, 52.

"Law of March 20, 1917.

${ }^{15}$ Cf. Innes, Law and Registration of Title in the Philippine Islands (1912) 28 Jour. Comp. Leg. 266. Also see Niblack, Pivotal Points in the Torrens System (IgI5) 24 Yale Law Journar, 274; Hogg, Registration of Title to Land (I918) 28 ibid., 5I; Hogg, Conveyances of Registered Land (1920) 29 ibid., $40 \mathrm{r}$. 
the direction of the English Society of Comparative Legislation some years ago four volumes ${ }^{16}$ were issued containing a review of the legislation for the years from 1898 to 1907 . In an introduction Sir John Macdonell observed:

"the history which the various statute books summarised in these volumes record seems to be everywhere similar. With much diversity of detail in this mass of legislation, it is surprisingly homogeneous; it has the same aims; it generally adopts the same means. Almost all the legislatures are making similar experiments, all making similar resolutions. The fact that for many parts of the Empire there is the same common law gives the legislation a similar character; much of it is intended to repair defects in that law or to adapt it to modern circumstances; for much of it there is a common background or substratum."

The general trend of the whole body of legislation, as Sir John Macdonell noted, which has been continued since he wrote, is the desire for amelioration of the conditions of life of the whole community; so that in this period of reconstruction when the main desire is to secure that the sacrifices which have been made shall bear fruit in the advancement of the national life, a survey of the legislation of the Empire has an especial value. In spite of the difficulties under which the work of the Society was carried on during hostilities the publication of the annual volume of the review of legislation has been continued without a break and announcement has been made of an intention to expand it. ${ }^{17}$ The Society has undertaken to develop its activities by co-operating with government departments and private organizations in collecting or supplying information much in the same way as is done by legislative reference bureaux.

The establishment in Canada of a body of Commissioners on Uniform Laws similar to the National Conference of Commissioners on Uniform State Laws, suggests the nucleus of an imperial body working in co-operation with the Imperial Conference. The primary cause leading to their formation has been the diversity of legislation with regard to commercial law which raises obstacles to closer business relationship. That operates to a greater or less degree throughout the Empire, so that a standing committee either of the Imperial Conference or some unofficial body dealing with uniformity of legislation is

\footnotetext{
${ }^{10}$ The Legislation of the Empire, being a Survey of the Legislative Enactments of the British Dominions from 1898 to 1907 , with a preface by the Rt. Hon. the Earl of Rosebery.

${ }_{17}$ Although the English Society has many good friends and supporters in the United States it is still perhaps not so widely known as it might be, and the developed scope both of the Journal and the review of legislation may reasonably be expected to lead to further additions to the membership. The address of the Society is I, Elm Court, Temple, E. C. 4 .
} 
an immediate desideratum. Such a body would naturally influence and be influenced by the United States Commissioners, so that the bond supplied by the common law would be strengthened and renewed by uniform statutory legislation in important subjects, such as is already in force in relation to bills of exchange. Ultimately the balance of convenience will no doubt lead to a general adoption of the AngloAmerican system, at all events in commercial matters, rather than the continuance of the divergencies now existing in continental law. The movement towards unity to be strong and healthy should proceed from below. Any attempt to impose it from above is almost useless. The practical value of disseminating widely the study of comparative legislation is, therefore, obvious, since only by that means can the general body of public opinion realize the obstacles to closer intercourse and appreciate the advantages to be derived from the adoption or avoidance of legislation in operation in other countries.

It may be concluded, therefore, that comparative jurisprudence has a double value at the present time. On the one hand it has a contribution to make to the effectiveness of the new international relations which are being established as a result of the war. The Secretariat of the League of Nations will need to be supported by strong national centres devoted to the collection and dissemination of information relating to the laws of other countries. France and England have for many years had their Societies of Comparative Legislation. The Comparative Law Bureau of the American Bar Association fulfills a corresponding function in the United States, though its work is somewhat dwarfed by official bodies and voluntary organizations concerned with the study of special subjects. ${ }^{18}$ The organization specially devoted to the study of comparative jurisprudence, whatever may be its precise constitution, has on the other hand a domestic as well as an international work. It can inform the Government, societies and individuals as to the laws and their working in other countries, so that legislation instead of being somewhat haphazard and piecemeal as it often is now, may be based upon the experience of other countries. While it cannot become a body to advocate special reforms it may readily stimulate interest in neglected subjects and direct attention to the treatment of matters which, if ignored, may readily develop into serious problems. It may be claimed without hesitation that the study of comparative jurisprudence is the most important field of legislative research at the present day.

\footnotetext{
${ }^{28}$ Attention is directed to the organization and aims of the International Intermediary Institute as revealed by Cyril M. Picciotto, of the Inner Temple, London, in CoMment (1919) 29 Yale LAW JourNaL, 209.
} 